UDC $\quad 669.14-404: 542.943: 546.72-31: 546.21$

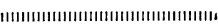

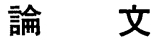

溶鉄の純酸素による酸化速度*

萬 谷志 郎**. 沈載 東***

\title{
Rate of Oxidation of Liquid Iron by Pure Oxygen
}

\author{
Shiro BAN-YA and Jae-Dong SHIM
}

Synopsis :

The rate of oxidation of liquid iron by oxygen gas has been studied using a volume constant technique.

The process of oxidation consists of two stages of very rapid oxidation in the early stage and relatively slow oxidation in the second stage after the formation of iron oxide covering the surface of melt. The rate of the dissolution of oxygen into the melt was studied under the presence of three phases of gas, liquid oxide, and liquid iron to make clear the mechanism of oxidation.

From the experimental results obtained, it was considered that the rate-determining step under the coexistence of three phases was the transport of solute gas through the stagnant layer in the oxide phase at the gas-oxide interface. This mechanism is supported by the following experimental facts: a) The rate of oxidation is proportional to the square root of oxygen pressure in the gas phase. b) The reaction rate decreases with decreasing the stirring of the melt. c) The rate is not influenced by the amount of oxygen and sulphur in liquid iron.

The apprarent activation energy of the reaction is low, giving a value of $5 \mathrm{kcal} / \mathrm{mol}$.

\section{1. 緒}

言

溶鉄の酸素ガスによる酸化速度は転炉製鋼法における 溶鋼の酸化，鋳造，造塊に括ける空気酸化と関連して重 要である．溶鉄の酸化速度に関しては，これまでいくつ かの研究が報告されてきた1) 5) L. A. GREenberg and A. $\mathrm{MCLEAN}^{2)}$ は高周波による浮遊溶融試料の $\mathrm{H}_{2}+\mathrm{O}_{2}$ 混合ガスによる酸化を测定し，律速段階としてガス相 での酸素の移動過程を報告している． S.K. VIG and $W-K . \mathrm{Lu}^{3)}$ も浮融溶融試料の落下途中の酸化を測定 し, 雾用気中の酸素が $10 \%$ 以下ではガス拡散律速を, $10 \%$ 以上では律速段階が変わつてくることを示唆して いる. るつぼ溶解による酸化速度に関しては T. Снон ら4)の研究があるが，前者と同様に混合ガスによる酸化 であるため雾用気中の酸素含量によつていろいろな律速 段階が提案されている. これらの研究では，いずれも酸 素分圧が低い、混合ガスによる酸化を扱つているため, 溶 鉄の表面に酸化膜が生成しない範用が測定の対象になつ ている. 従つて, 雲囲気中での反応ガスの拡散も反応速 度に大きな影響を与えている。

本研究では溶鉄の表面に酸化膜が生成した場合の酸化
速度を測定することを目的とし，純酸素による溶鉄の酸 化を行つた，実験方法としては，改良 Sieverts 反応管 を用い，既知容積の反応系に酸素ガスを導入し，その圧 力変化を測る定容測圧法を採用した. この方法による溶 鉄の酸化については, 既に $T$. EMI 556) の研究があ り，律速段階として EHRLICH の吸着平衡モデル7)によ るガス/酸化物界面での界面反応律速を報告している・し かし，その結果には 2,3 疑問が持たれる。

そこで，ここでは，いくつかの律速過程を仮定して測 定值の解析を行うとともに反応速度に拈よぼす $2 \sim 3$ の 要因の影響を定量的に測定することによつて溶鉄の酸化 速度に関する律速機構を検討した.

\section{2. 実 験 方 法}

\section{$2 \cdot 1$ 実験装置}

実験装置の概略と反応管の内部構造を Fig. 1 および Fig. 2 に示す. 実験装置は反応管, 定容ガス貯蔵器, ガ ス精製装置および排気装置の各部よりなる，反応管は内 径 $55 \mathrm{~mm}$, 長さ $140 \mathrm{~mm}$ の透明石英管であり，その下 部には水冷キャップがすり合わせて取り付けられてい る. 溶解用のるつぼは内径 $16 \sim 25 \mathrm{~mm}$, 長さ $45 \mathrm{~mm}$ の

* 昭和 52 年 10 月本会講演大会にて発表 昭和 54 年 1 月 7 日受付 (Received Jan. 7，1979)

** 東北大学工学部 工博 (Faculty of Engineering, Tohoku University, Aza-Aoba Aramaki Sendai 980)

*** 東北大学工学部 (現：韓国科学技術研究所) (Faculty of Engineering, Tohoku University, Now Korea Institute of Science and Technology, Seoul, Korea) 


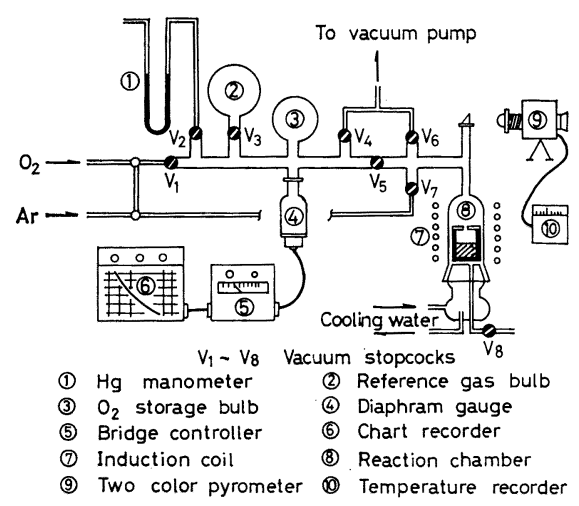

Fig. 1. Experimental apparatus.

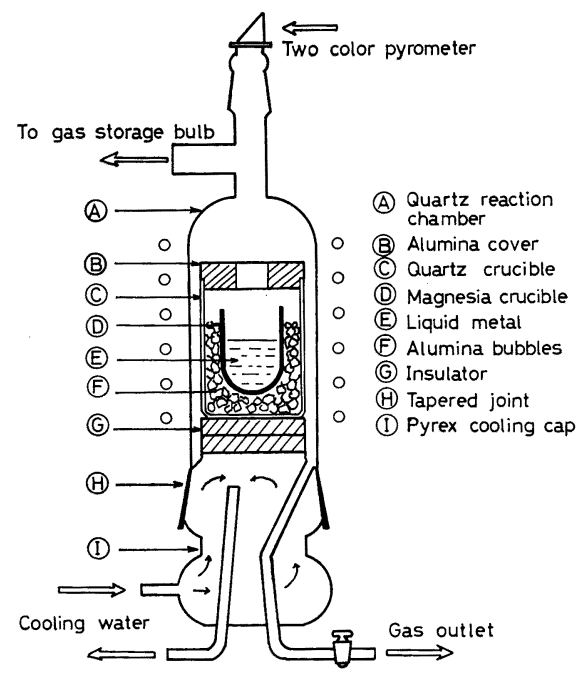

Fig. 2. Reaction chamber of apparatus.

市販のマグネシヤるつぼである.マグネシヤるつぼは内 径 $44 \mathrm{~mm}$ 石英保護るつぼに入れ，その間には保温をよ くするため再結晶アルミナ粒を充填する.

内容積 678 cc の定容ガス貯蔵器には, 微小生力測定 用の歪みゲージと圧力補正用の水銀マノメータが取り付 けられている，歪みゲージによつて探知される系内の酸 素圧の変化はブリッジコントローラー (Bridge controller) より電気的信号に変換され，記録計に連続的に 記録される．溶解用の加熱炉は $10 \mathrm{kVA}$ 真空管式高周 波炉であり，試料の温度は純鉄の融点から温度補正を行 つた二色高温計で測定した. 装置の排気は水銀拡散ポン プと油回転ポンプよりなり, 系内の真空度はマクレオド ゲージで測定した.

\section{2 使用試料}

溶解用の純鉄試料としては，市販の丸棒電解鉄を用い，
一回の溶解量は $50 \mathrm{~g}$ である.試料のおもな稀純物として は, $\mathrm{C}<0.003 \%, \mathrm{Si}<0.007 \%, \mathrm{~S}<0.005 \%, \mathrm{P}<0.004$ $\%, \mathrm{O}<0.005 \%$ である. $\mathrm{Fe}-\mathrm{O}$ および $\mathrm{Fe}-\mathrm{S}$ の合金系 に対しては，研究室で作製したりスタイトおよび $35 \%$ $\mathrm{FeS}$ を適当量添加した.

\section{3 実験方法}

電解鉄試料をマグネシャるつぼに人れ，人伈管卜部よ り装入する. 反応管拉よびガス貯蔵器の内部を十分に排 気したのち，ガス精製装置から精製 Ar を約 $100 \mathrm{ml}$ min の流量で反応管に流す。なお, 定容ガス貯蔵器には 純酸素を所定の圧力まで入れる. Ar 扎よび $\mathrm{O}_{2}$ は市販 のボンベガスであるが $\mathrm{O}_{2}$ の場合には最高純度のものを 用い，さらに精製装置を通して使用した，反応管内部を Ar で十分に置換したのち，Ar 気流中で試料の加熱を 開始する. 加熱時間 $1.5 \mathrm{~h}$ で試料の溶解を行い測定温度 まで温度を上げる，必要の場合には反心管上部の測温用 プリズムをはずしてサンプリングを行う，その後，高周 波炉の微小電力を調整し試料の温度を正確に調整する. 試料の温度が安定したら，コック $\mathrm{V}_{7}$ およびコック $\mathrm{V}_{8}$ を締め反応管の内部を排気する．排気の時には溶鉄が蒸 発して反応管の内壁に蒸着する。その蒸着量はできるだ け少ないことが望ましく, 約 $60 \mathrm{~s}$ 程度, 系内の真空度が $10^{-3} \mathrm{mmHg}$ になるまで真空に排気する。排気のあと, すばやくコック $\mathrm{V}_{5}$ を開き， $\mathrm{O}_{2}$ を反心管に導入し溶鉄 の酸化反応を行わしめる.酸化反応にともなら系内の酸 素圧の変化は歪みゲージによつて測定して記録計に記録 される． $\mathrm{O}_{2}$ が反応によつてだんだん消費され系内が真 空状態になるまで測定をつづける， $\mathrm{O}_{2}$ 中の不純ガスの 混入は反応速度に大きく影響するため，反応の終点で系 内が高真空とならない場合には測定值から除外した。

\section{3. 実 験 結 果}

\section{1 溶鉄の酸化過程}

溶鉄の酸化過程に叔ける系内の酸素圧の変化の記録例 を Fig. 3 に示す. 同図からわかるよらに系内の酸素圧 は, 反応開始とともに瞬問的に大きく低下する段階と比 較的ゆつくり低下する段階にはつきりとわけられる。

二色高温計から溶鉄の表而を観祭すると, $\mathrm{O}_{2}$ の尊 入と同時に溶鉄の表面は急に明るくなり，表面温度も $1900^{\circ} \mathrm{C}$ 以上に達する。この時の表而状態は明るさのた め判断することができないが，これは瞬間的な現象であ つて，2〜3 s 経過すると，表面に無数の小さな円状の 酸化物が活発に動きまわり，ついに表面は酸化物によつ て均一に抹われることが観測される。この時点で表面 の温度は $1700^{\circ} \mathrm{C}$ 以下まで降下し，以後は反伈の進行之 


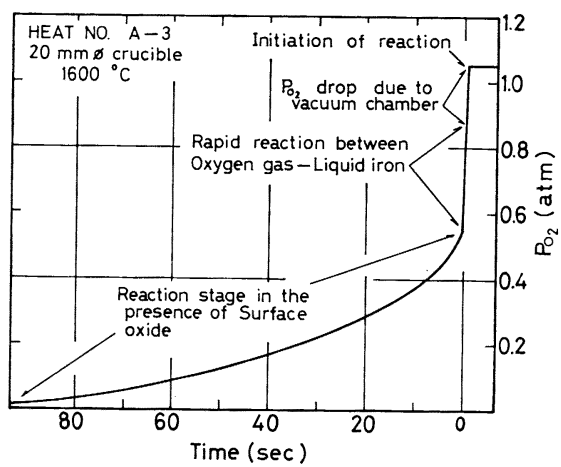

Fig. 3. An example of variation of oxygen pressure in reaction bulb for oxidation process.

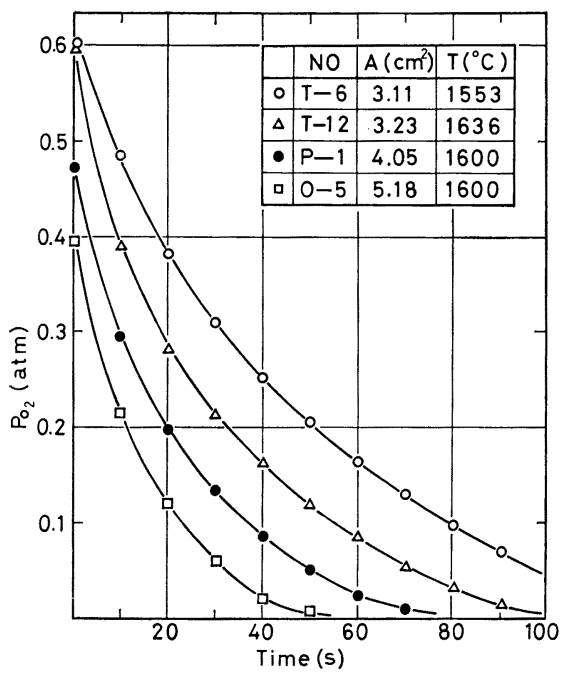

Fig. 4. Rate of oxidation in the presence of oxide phase covering the melt.

ともに反応管内酸素圧はゆつくりと低下していく，以上 の状況から見ると, 反応初期に打ける急激な酸素圧の減 少は, 酸素之溶鉄の直接接触に上る激烈な酸化反応が原 因であると思われ，表面温度が急に上昇するのも酸化反 応による発熱のためであると考えられる。

一方, 酸素-溶鉄間の直接反応が 終わると, 溶鉄の表 面は酸化膜で完全に拈拈われ，酸素と溶鉄の直接接触は なくなるため以後の反応は，酸化膜を通しての反応，す なわち，ガス/酸化物/メタルの 3 相共存に扣ける不均一 反応に上つて行われ，溶鉄の酸化はFig. 3 の曲線で示 されるよらにゆつくり進行するものと考光られる。

以上で見るように, 酸化の初期段階はガスーメタルの直 接的な化学反心汇上る酸化物の生成段階であつて，その 反応は極めて短時間で終了してしまらため，その変化の
過程を測定することは困難である。しかし，酸化物が存 在する場合以は酸化反応は比較的ゆつくり進行し，十分 再現性のある測定が可能であり，本研究の測定はこの段 階の酸化を対象としている. Fig. 4 にガス/酸化物/ ×夕 ル共存時の不均一反応に强忛る系内の酸素圧之反応時間 の関係について $2 ， 3$ の実例を示すが，反応速度はいず 北の場合でも反応初期速く，時間の経過とともに低下 する.

\section{$3 \cdot 2$ 律速段階の検討}

前述したように，金属表面が酸化物で扮抒われ，ガス /酸化物/×タル共存下での酸化速度は比較的ゆつくり進 行するが，この段階での反応過程を素過程に分けて考兄 ると次のように表すことができる。

A）ガス相に抢ける反忍ガスの拡散

B）ガス/酸化物界面のガス側境界層に㨟ける物質移 動

C）ガス/酸化物界面にお叔る界面反応

D）ガス/酸化物界面の酸化物側境界層に拈汀る物質 移動

E）酸化物本体中に打忛る反応物質の拡散

F) 酸化物/メタル界面の酸化物側境界層に抢汀る物 質移動

G）酸化物/メタル界面の界面反応

H）酸化物/メタル界面のメタル側境界層に抢计る物 質移動

I ) メタル本体中に拈汁る拡散

上記の過程中最も括そい過程が律速段階として，全体 の反応速度を左右する．ところが本研究のように反応が スとして自由膨張する純粋なガスを用いる場合にはＡ） およびB）の過程は律速段階とはなりえないと考えられ る。また，少量の試料を高周波炉にて溶解する場合には 溶鉄唍全に攪拌され，濃度均一の溶体之見なされる。 そのらえ，後述するょらに反応速度が溶鉄中の酸素の含 量に関係なく一定であつたことから F ) 〜 I ) の過程は 律速段階から除外することができる。従つて，ここでは C)，D)，E）のいずれかの過程が律速段階子考光，以 後これらについて検討してみる.

$3 \cdot 2 \cdot 1$ ガス/酸化物の界面反応律速モデル

ガス/酸化物界面に拈ける不均一反応はつぎの上らな 総括反応で示すことができる.

$$
\mathrm{O}_{2} \text { (gas) }+4 \mathrm{FeO}=2 \mathrm{Fe}_{2} \mathrm{O}_{3}
$$

一般的に，ガス一凝縮相間の不均一反応は，反応分子の解 離，ガス原子の表面吸着などを含む素過程にわけて考兄 ることができる．特に酸化反応に関する吸着平衡につい てはいろいろなモデルが提案され，測定值と比較的一致 
する反応機構も提出されている. しかし，酸化物表面に おける吸着種の性質や表面結合状態などについてはあま り知られていないので表面反応を更にいくつかの素過程 にわけて考えることは困難である．従つて，ここでは (1) 式で示される量論式より一次反応を仮定すれば界面 反応の総括速度として $(2)$ 式が得られる. 同式で逆反応 を無視したのは，溶融酸化物と平衡する酸素分圧が約 $10^{-8} \mathrm{~atm}\left(1600^{\circ} \mathrm{C}\right.$ 前後)で非常に低いからである.

$$
-d n_{\mathrm{O}_{2}} / d t=A \cdot k_{\mathrm{C}} \cdot P_{\mathrm{O}_{2}}
$$

$n_{\mathrm{O}_{2}}$; 酸素の $\mathrm{mol}$ 数 $(\mathrm{mol})$

$A ;$ 反応界面積 $\left(\mathrm{cm}^{2}\right)$

$P_{\mathrm{O}_{2}}$; 反応系の酸素圧 $(\mathrm{atm})$

$k_{\mathrm{C}}$; 反応速度定数 $\left(\mathrm{mol} / \mathrm{cm}^{2} \cdot \mathrm{atm} \cdot \mathrm{s}\right)$

$t$; 反応時間 $(\mathrm{s})$

$P_{\mathrm{O}_{2}} \cdot V=n_{\mathrm{O}_{2}} \cdot R T$ の関係を(2) 式に代入すると $(3)$ 式 が得られる.

$$
\begin{gathered}
-d P_{\mathrm{O}_{2}} / d t=A \cdot k_{\mathrm{C}} \cdot(R T / V) \cdot P_{\mathrm{O}_{2}} \cdots \\
V \text {; 反応系の定容積 }\left(\mathrm{cm}^{3}\right) \\
T \text {; 反応系のガス温度 }(\mathrm{K}) \\
R \text {; 気体定数 }\left(1 \cdot \mathrm{atm} / \mathrm{mol}^{\circ} \mathrm{G}\right)
\end{gathered}
$$

$t=0$ で $P_{\mathrm{O}_{2}}=P_{\mathrm{O}_{2}}^{0}$ とし，（3)式を積分すると（4)式が 得られる.

$$
\ln \left(P_{\mathrm{O}_{2}}^{0} / P_{\mathrm{O}_{2}}\right)=k_{\mathrm{C}} \cdot(A R T / V) \cdot t
$$

$P_{\mathrm{O}_{2}}^{0}$ 快測定の初期条件によつて決まる定数であるか ら測定值が (4) 式を満足するならば, $\ln \left(P_{\mathrm{O}_{2}}^{0} / P_{\mathrm{O}_{2}}\right)$ 之 $(A R T / V) \cdot t$ の間には直線関係で示され，酸化速度はガ ス/酸化物界面の界面反応によつて律速されると考える ことができる。

\section{$3 \cdot 2 \cdot 2$ 物質移動律速モデル}

酸化速度が前述の過程 (D)すなわち,ガス/酸化物界面 の酸化物側境界層における物質移動により律速されると すれば次式を得る。

$$
-d n_{\mathrm{O}} / d t=A k_{\mathrm{L}}\left(C_{\mathrm{O}}-C_{\mathrm{O}^{\prime}}\right)
$$

$n_{\mathrm{O}} ;$ 酸素原子の $\mathrm{mol}$ 数 $(\mathrm{mol})$

$k_{\mathrm{L}} ;$ 物質移動係数 $(\mathrm{cm} / \mathrm{s})$

$C_{\mathrm{O}}, C_{\mathrm{O}}{ }^{\prime}$; 酸化物相の表面抏よびバルク中酸素濃度 $\left(\mathrm{mol} / \mathrm{cm}^{3}\right)$

しかし，溶融酸化鉄の物理化学的性質は複雑でありか つ測定困難なためいまだ不明な点が極めて多い，例えば 酸素ポテンシャルの異なる溶融酸化鉄相内ではいかなる イオン種又は分子種が移動するのか，またその拡散係数 の值などは不明である。したがつて，(5)式で定義され た物質移動係数の物理的意味は不明であり，駆動力とし ての $\left(C_{\mathrm{O}}-C_{\mathrm{O}^{\prime}}\right)$ として何を取るべきかも厳密には分から ないのが現状である。しかし，一般の溶融酸化物中に拉
ける自己拡散の值を比較すれば酸素の值が最も大きいこ と，拈よび( 5 )式に打ける右辺と左辺の形式と単位を整 えるため, 本研究では移動する原子種として単純に酸化 鉄中の酸素（O）を仮定した. このよらな仮定の下で, 酸素圧と酸化鉄間の平衡関係を示す平均的な見掛けの平 衡定数を $K^{\prime}$ とすれば次式の関係がある.

$1 / 2 \mathrm{O}_{2}(\mathrm{~g})=(\mathrm{O})$ (in iron oxide)

$$
K^{\prime}=\left(C_{\mathrm{O}}\right) / \sqrt{P_{\mathrm{O}_{2}}} \text {. }
$$

(5),（7)式を組み合わせ, 更に化学量論的関係 $n_{\mathrm{O}}=$ $2 n_{\mathrm{O}_{2}}$ を入れて式を整理すれば次式を得る。

$$
\begin{aligned}
-d n_{\mathrm{O}_{2}} / d t & =A \cdot k_{\mathrm{L}} \cdot K^{\prime}(1 / 2)\left(\sqrt{P_{\mathrm{O}_{2}}}-\sqrt{P_{\mathrm{O}_{2}{ }^{\prime}}}\right) \\
& =A \cdot k_{\mathrm{m}}\left(\sqrt{P_{\mathrm{O}_{2}}}-\sqrt{P_{\mathrm{O}_{2}}{ }^{\prime}}\right) \cdots \cdots \cdots(
\end{aligned}
$$

ただしここで

$$
k_{\mathrm{m}}=(1 / 2) k_{\mathrm{L}} K^{\prime}
$$

上式に拈いて $P_{\mathrm{O}_{2}}$ は実験中の酸素圧で $P_{\mathrm{O}_{2}}=100$ 〜 10-2 $(\mathrm{atm})$ であるのに対して, $P_{\mathrm{O}_{2}}{ }^{\prime}$ は溶鉄と平衡する溶 融酸化鉄の酸素圧であり $P_{\mathrm{O}_{2}}{ }^{\prime} \fallingdotseq 10^{-8}(\mathrm{~atm})$ が予想され， $P_{\mathrm{O}_{2}} \gg P_{\mathrm{O}_{2}}{ }^{\prime}$ である.また $P_{\mathrm{O}_{2}} V=n_{\mathrm{O}_{2}} R T$ より, 次式を得る。

$$
-d P_{\mathrm{O}_{2}} / d t=k_{\mathrm{m}} \cdot(A R T / V) \sqrt{P_{\mathrm{O}_{2}}} \text {. }
$$

(10) 式を $t=0$ で $P_{\mathrm{O}_{2}}=P_{\mathrm{O}_{2}}^{0}$ として積分すれば次式の ようである。

$$
2\left(\sqrt{P_{\mathrm{O}_{2}}^{0}}-\sqrt{P_{\mathrm{O}_{2}}}\right)=k_{\mathrm{m}}(A R T / V) t
$$

上式より, 物質移動律速では, 酸化速度は $\sqrt{P_{\mathrm{O}_{2}}}$ に比 例し, $\sqrt{P_{\mathrm{O}_{2}}}$ と時間 $t$ の間には直線関係があると考え られる。

\section{$3 \cdot 2 \cdot 3$ 酸化物層の拡散律速モデル}

酸化物層に拈ける反応物質の拡散過程が律速段階の場 合には, 酸化反応は放物線 (parabolic law) に従つて 進行することが予想される，Parabolic oxidation に関 する酶:化機構については WAGNER ${ }^{8)}$ による機構が提案 されている．これは酸化物層に打けるイオンの体積拡散 が全体反応の律速段階であるという前提から成立してい る.すなわち，メタル/酸化物の界面からガス/酸化物界 面に向かつて陽イオンの抎散が行われるのに対し, 反対 の方向に向かつて陰イオンの拡散が行われ, 酸化物層で は陽イオン空孔の濃度勾配が生じ, 酸化物層の生成速度 はその濃度勾配による払散速度によつて支配される。こ のような parabolic oxidation の場合, 酸化による試料 の重量変化はつぎのように示される.

$$
\begin{aligned}
\Delta m^{2} & =k_{p} \cdot t+C \\
\Delta m & ; \text { 重量変化 }\left(\mathrm{g} / \mathrm{cm}^{2}\right) \\
k_{\mathrm{p}} & ; \text { parabolic 定数 }\left(\mathrm{g}^{2} / \mathrm{cm}^{4} \cdot \mathrm{s}\right)
\end{aligned}
$$

また，ガス相に括ける酸素の $\mathrm{mol}$ 数の変化 $\Delta n_{\mathrm{O}_{2}}$ と $\Delta m$ の間には $\Delta n_{\mathrm{O}_{2}} \cdot M_{\mathrm{O}} / A=\Delta m$ の関係があり，これに 
$\Delta P_{\mathrm{O}_{2}} \cdot V=\Delta n_{\mathrm{O}_{2}} \cdot R T$ の関係を代入して (13) 式が得られ る.

$$
\Delta m=\left(V M_{\mathrm{O}} / A R T\right) \cdot \Delta P_{\mathrm{O}_{2}}
$$

$M_{\mathrm{O}}$ は酸素の分子量であり， $\Delta P_{\mathrm{O}_{2}}$ は系内の酸素圧の 変化である. (12) (13) 式から(14)式が得られる.

$$
\Delta P_{\mathrm{O}_{2}}=\left(A R T / V \cdot M_{0}\right) \cdot k_{\mathrm{p}}^{\prime} \cdot \sqrt{t}
$$

ただし，

$$
k_{\mathrm{p}}^{\prime}=\sqrt{k_{\mathrm{p}}}
$$

(14)式によつて, 酸化物層に打ける拡散過程, すなわち, 酸化物層の成長が律速段階の場合には， $\Delta P_{\mathrm{O}_{2}}$ と $V \bar{t}$ の間には直線関係が成立する。

以上，律速になりうる 3 つの段階についてのべたが，

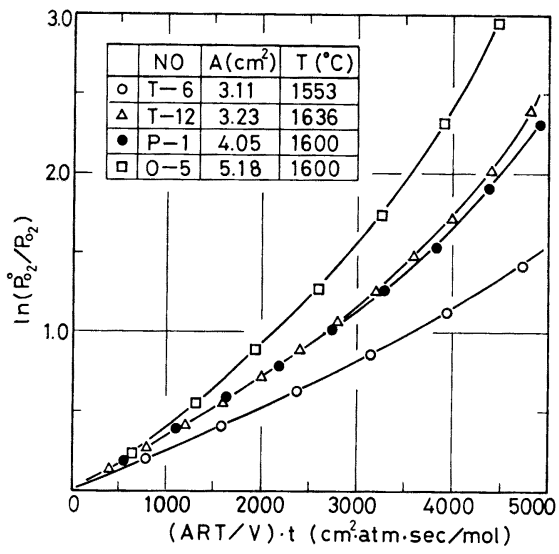

Fig. 5. Correlation of experimental results on the basis of chemical reaction model at the gas/oxide interface.

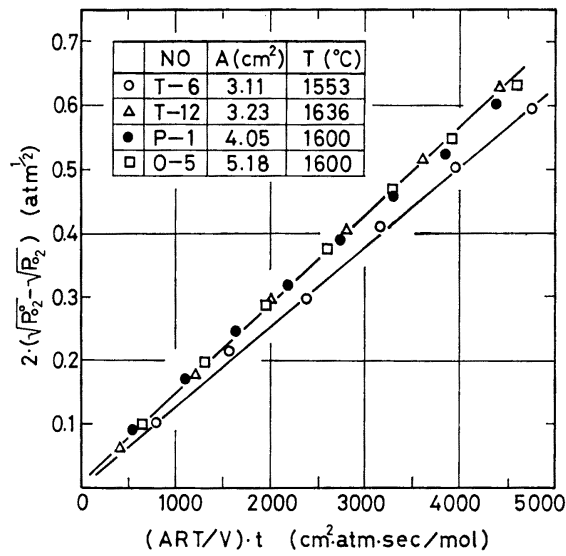

Fig. 6. Correlation of experimental results on the basis of mass transport model through the oxide phase boundary layer adjacent to gas/oxide interface.
次節では実測值に基づいてこれらの段階について検討す る.

\section{$3 \cdot 3$ 測定結果の検討}

前述の C)，D），E）の過程中どちらが律速になるか を調べるためには，まず測定結果がどの速度式を満足し ているかを見ればよい．Fig. 4 に示す測定結果を(4) 式，(11)式および(14)式に従つて図示したのが Fig. 5〜 Fig. 7 である. 同図より明らかなように（4)式で示さ れる界面反応律速特よび(14) 式で示される酸化物層に括 ける拡散律速に従い図示した Fig. 5 执よび Fig. 7 で は，直線関係が成立しない。しかし (11) 式で示される ガス/酸化物界面の酸化物境界層に括ける物質移動律速 に従つて図示した Fig. 6 では $\left(\sqrt{P_{\mathrm{O}_{2}}^{0}}-\sqrt{P_{\mathrm{O}_{2}}}\right)$ と $(A R T / V) \cdot t$ の間にきわめてよい直線関係が得られる が，この関係は後述する $\mathrm{Fe}-\mathrm{O}$ 特よび $\mathrm{Fe}-\mathrm{S}$ の合金系 に拈いても同様に成立している．以上の結果より溶鉄の

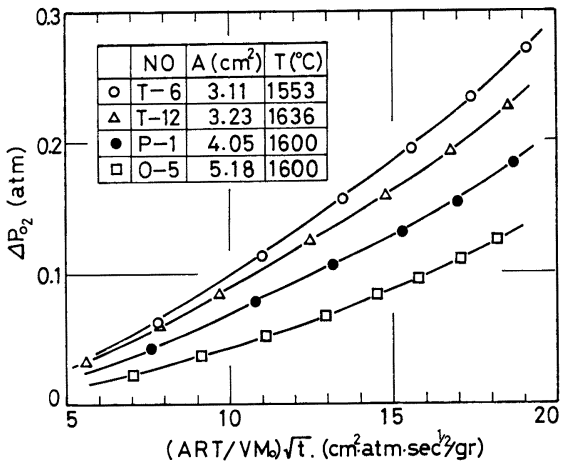

Fig. 7. Correlation of experimental results on the basis of parabolic oxidation model.

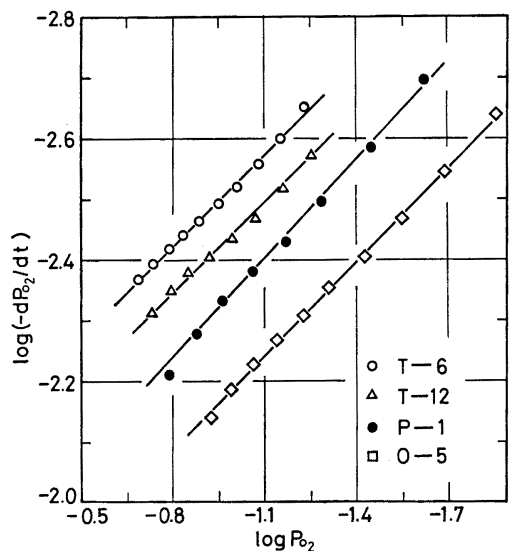

Fig. 8. Differential plot of Experimental results for oxidation rate. 
Table 1. Values of apparent rate constants, $k_{\mathrm{m}}$, obtained on the basis of the model of mass transport through the oxide phase boundary layer adjacent to the gas/ oxide interface at $1600^{\circ} \mathrm{C}$.

\begin{tabular}{|c|c|c|c|c|c|c|}
\hline \multirow{2}{*}{$\begin{array}{l}\text { Heat } \\
\text { No. }\end{array}$} & \multirow{2}{*}{$\begin{array}{c}A \\
\left(\mathrm{~cm}^{2}\right)\end{array}$} & \multirow{2}{*}{$\begin{array}{c}P_{\mathrm{O}_{2}}^{\mathrm{b}} \\
(\mathrm{mmH})\end{array}$} & \multirow{2}{*}{ Systems } & \multicolumn{2}{|c|}{$k_{\mathrm{m}} \times 10^{4}\left(\mathrm{~mol} / \mathrm{cm}^{2} \cdot \mathrm{atm}^{1 / 2} \cdot \mathrm{s}\right)$} & \multirow{2}{*}{$\begin{array}{c}\text { Order of reaction } \\
n\end{array}$} \\
\hline & & & & Integral & Differential & \\
\hline $\mathrm{P}-2$ & 4.11 & 800 & Pure $\mathrm{Fe}$ & 1.406 & 1.427 & 0.508 \\
\hline $\mathrm{P}-3$ & 4.21 & 760 & " & 1.499 & 1.475 & 0.505 \\
\hline $\mathrm{P}-7$ & 4.17 & 512 & " & 1.354 & 1.372 & 0.504 \\
\hline $\mathrm{A}-2$ & 3.33 & 803 & " & 1.412 & 1.420 & 0.506 \\
\hline A -4 & 2.11 & 797 & " & 1.464 & 1.420 & 0.482 \\
\hline A L -2 & 5.23 & 800 & " & 1.433 & 1.432 & 0.500 \\
\hline $\mathrm{O}-2$ & 5.23 & 804 & $222 \mathrm{ppm} \mathrm{O}$ & 1.406 & 1.475 & 0.513 \\
\hline $\mathrm{O}-5$ & " & 795 & $1321 \mathrm{ppm} \mathrm{O}$ & 1.391 & 1.432 & 0.515 \\
\hline $\mathrm{O}-8$ & $"$ & 802 & $585 \mathrm{ppm} \mathrm{O}$ & 1.401 & 1.420 & 0.511 \\
\hline $\mathrm{O}-12$ & " & $\varepsilon 02$ & $1653 \mathrm{ppm} \mathrm{O}$ & 1.412 & 1.432 & 0.511 \\
\hline $\mathrm{S}-1$ & 5.18 & 798 & $0.10 \% \mathrm{~s}$ & 1.422 & 1.468 & 0.520 \\
\hline $\mathrm{S}-4$ & 5.14 & 800 & $0.51 \% \mathrm{~S}$ & 1.366 & 1.348 & 0.490 \\
\hline$S-6$ & 5.23 & 800 & $1.01 \% \mathrm{~S}$ & 1.309 & 1.322 & 0.504 \\
\hline$S-8$ & 5.18 & 800 & $1.20 \% \mathrm{~S}$ & 1.256 & 1.264 & 0.491 \\
\hline
\end{tabular}

Note. $A$ : Surface area, $P_{\mathrm{O}_{2}}^{\mathrm{b}}:$ Initial $\mathrm{O}_{2}$ pressure in the gas storage bulb.

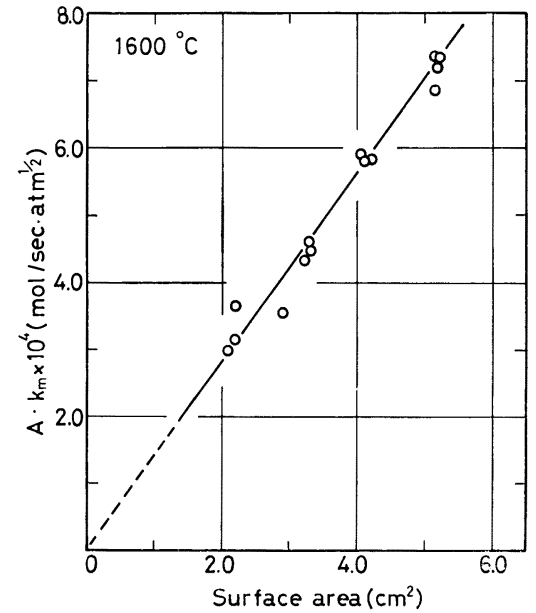

Fig. 9. Effect of surface area on the apparent rate constant $k_{\mathrm{m}}$ at $1600^{\circ} \mathrm{C}$.

酸化速度 $\left(d P_{\mathrm{O}_{2}} / d t\right)$ は $\sqrt{P_{\mathrm{O}_{2}}}$ に比例し, ガス/酸化物 界面の酸化物側境界層に打ける物質移動によつて律速さ れるものと推論される.

以上は積分法による解析結果であるが，微分法によつ て解析した場合にもまつたく同一の結果が得られた. Fig. 8 は縱軸に $\log \left(-d P_{\mathrm{O}_{2}} / d t\right)$, 横軸に $\log P_{\mathrm{O}_{2}}$ を取 つてプロットしたものであるが，直線の公配から反応次 数 $n$ を求めると約 0.5 となり, 縦軸の切片から求めた見 掛けの速度定数 $k_{\mathrm{m}}$ の值も Table 1 で見るように積分 法で得られた結果とほぼ一致している.

Fig. 9 は反応界面積 $A$ を $2.0 \sim 2.5 \mathrm{~cm}^{2}$ に変化させ， その影響を調べたものである・A・ $k_{\mathrm{m}}$ の值は原点を通る 直線で示され， $k_{\mathrm{m}}$ の値は反応界面積に関係なく一定で

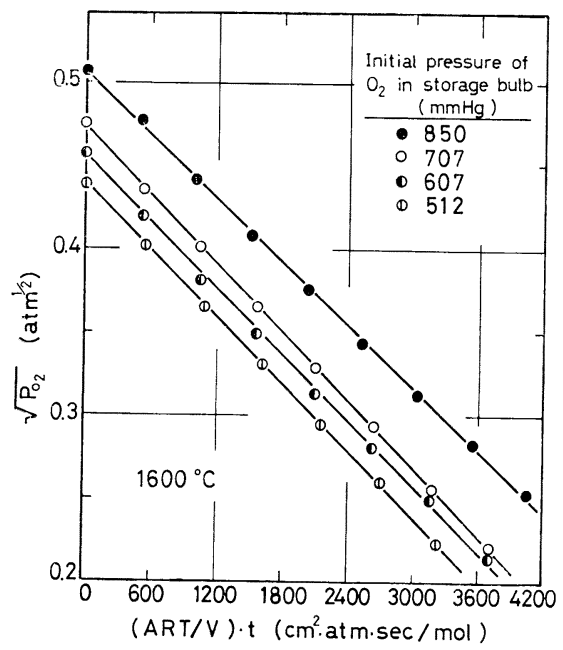

Fig. 10. Effect of initial oxygen pressure in gas storage bulb on oxidation rate at $1600^{\circ} \mathrm{C}$.

あることがわかる、つぎに，ガス貯蔵器の初期酸素圧を $400 \sim 850 \mathrm{mmHg}$ の籁囲で変化し，初断送人陵素旨の影 響を調べた。その結果は Fig. 10 でホすように初期酸 素圧に関係なく(12)式を満足し，すべての四線は平行で $K_{\mathrm{m}}$ の值は一定であることが分かつた.

以上のように測定条件に夙係なく $k_{\mathrm{m}}$ の傎は一这であ り，物質移動律速に上く一致している。しかし速度式の 設定に扣いては素過程に関する考え方によつて遠いが出 てくる場合もありらることを考えれば，モデルによる測 定值の解析のみで律速機椪を判断するのは十分とはい学 ないそこで，次章からは反忍速度に拈上ぼす2，3の 要因の影響について考察した 


\section{4. 考}

察

\section{1 溶体の挸拌の影響}

律速段階を调べる最も有力な手段としては，界面積一 定の条件で㩭拌の影響を調べることがあげられ，その影 響があれば物質移動律速，な祆机反応律速と考えるこ とができる. 本研究では，厚さ $0.1 \sim 0.3 \mathrm{~mm}$ のモリブ デニウムおよび $0.15 \mathrm{~mm}$ 白金シールド板をるつぼのま わりに巻いて溶解を行い高周波による攪汼の影響を試し た，高周波溶解の場合，溶体との間に誘導しやすいシー ルド板を用いると，溶体表面の電流密度が減少するため 溶体の攪拌が鈍くなることはよく知られている。モリブ デニウムの場合には酸化を防止するため緻密につめたマ グネシヤ粉末中に埋没して使用した．Fig．11 にとの結 果を示すがシールド板を用いた場合には，反応速度はい ずれも大きく減少し，な抢，その厚さが厚い核ど減少の 傾向は大きい，Table 2 にそれぞれのシールド板に対す る $k_{\mathrm{m}}$ の值を比較したが，シールド板のない場合に対し

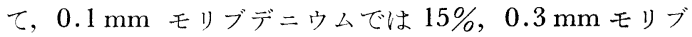
デニウムでは $30 \%, 0.15 \mathrm{~mm}$ 白金では $24 \%$ も減少し ている。このよらに反心速度が溶体の揬拌に大きく影響

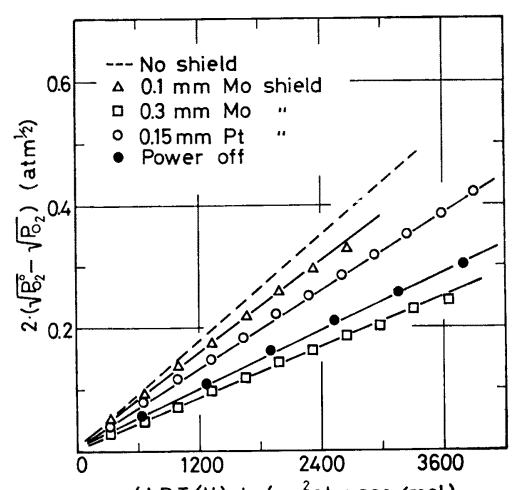

$(A R T / V) \cdot t \quad\left(\mathrm{~cm}^{2} \cdot \mathrm{atm} \cdot \mathrm{sec} / \mathrm{mol}\right)$

Fig. 11. Effect of induction stirring of the melt on the apparent rate constant at $1600^{\circ} \mathrm{C}$.

Table 2. Effect of the induction stirring of the melt on the apparent rate constant.

\begin{tabular}{ccccc}
\hline $\begin{array}{l}\text { Heat } \\
\text { No. }\end{array}$ & $\begin{array}{c}W \\
(\mathrm{~g})\end{array}$ & $\begin{array}{c}A \\
\left(\mathrm{~cm}^{2}\right)\end{array}$ & Susceptor & $k_{\mathrm{m}} \times 10^{4}$ \\
\hline N S-1 & 50 & 5.18 & None & 1.425 \\
MO-3 & 50 & 5.28 & $0.1 \mathrm{~mm} \mathrm{Mo}$ & 1.215 \\
MO-6 & 50 & 5.23 & $0.3 \mathrm{~mm} \mathrm{Mo}$ & 0.720 \\
F S-1 & 50 & 5.14 & $0.15 \mathrm{~mm} \mathrm{Pt}$ & 1.086 \\
P O-2 & 50 & 5.02 & Power off & 0.714 \\
\hline
\end{tabular}

$W:$ Melt weight
されることから，前述の物質移動律速は妥当なるのと考 えられる.ところが，T. Емі and R. D. PенLKE ${ }^{5)}$ は 反応系に酸素を導入する直前汇高周波の出力を切断した 状態で測定を行ない攪找の影響はないと報告している. 彼らの研究で界面反応律速が提案されたのはここに大き な根拠をるつていると思われる. 本研究でも同様の方法 で測定してみたが Fig. 11 で見るように T. EMI らとは 異なつた結果が得られた。この場合には試料の温度が大 きく低下するので, 反応速度の減少には温度の影響も無 視できないほど作用するるのと考兄られる。

\section{2 溶鉄中の酸素および硫黄の影響}

溶鉄中の酸素濃度を $1650 \mathrm{ppm}$ まで变化させ, その影 響を調べ，これをFig. 12 と示す. 同図から Fe-O 合 金系に打いても測定值は物質移動律速を表す(12) 式によ つて整理することができ，酸化速度は溶鉄中の酸素量に 関係なく一定であることがわかる。これは $T$. EMI ら の研究とも一致する結果である。このように溶鉄中の酸 素の影響がないことは，物質移動律速の場合，予想でき る現象であり，酸化物/×タル界面の界面反応あるいは 溶鉄中の拡散過程などは律速段階ではないことを示する のと考えられ，F）～I）の諸過程を律速段階から除外 した前述の仮定は妥当であると考光られる.

溶鉄中の硫黄は表面活性元素として働き，溶鉄の表面 張力を低下させる元素として知られている9)。このよう な表面活性元素の存在は溶鉄表面の物理化学的性質の変 化をもたらすため，溶鉄のガス吸収速度も大きく変わつ てくる。これまで溶鉄のガス吸収速度に抢よぼす硫黄の 影響についてはいくつかの研究があるが，例えば， $W$. $M$. Boostein ら ${ }^{10)}$ の水素吸収速度，R. D. Pehlke ら ${ }^{11)}$ 打よび長・井上ら ${ }^{12)}$ の窒素吸収速度, 萬谷ら ${ }^{13)}$ の 脱窒速度の研究では, 少量の硫黄の添加によつて反応速 度は大きく低下している。これは硫黄がガス/メタル界 面に掠けるガスの吸着めるいは脱着過程に毒作用するこ

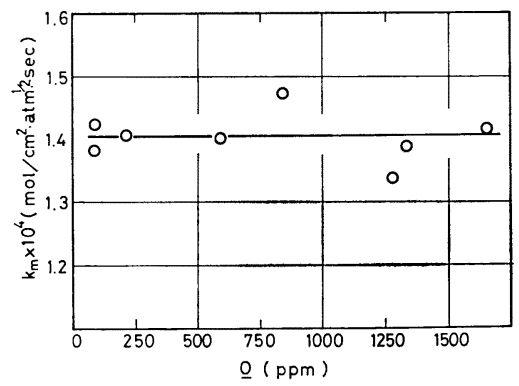

Fig. 12. Effect of oxygen content in Fe-O melt on the apparent rate constant at $1600^{\circ} \mathrm{C}$. 


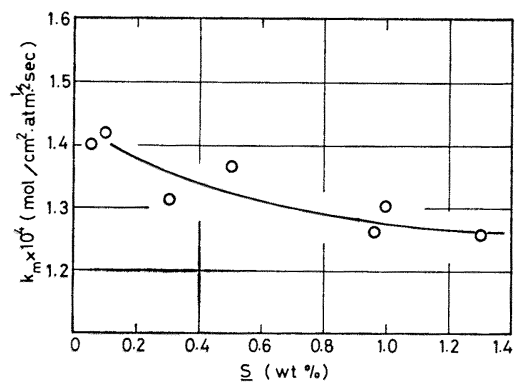

Fig. 13. Effect of sulfur content in Fe-S melt on the apparent rate constant at $1600^{\circ} \mathrm{C}$.

とが原因としてあげられる。本研究では $1.3 \% \mathrm{~S}$ までの 範囲で酸化速度を測定したが，Fe-S 系においても酸化 速度は $\sqrt{P_{\mathrm{O}_{2}}}$ に比例することがわかり, 硫黄の毒作用 に基づく律速段階の変化はないことが予想される. Fig. 13 に見掛忊の速度常数 $k_{\mathrm{m}}$ と硫黄の関係を示すが， $k_{\mathrm{m}}$ の值は硫黄の増加とともに少々減少する傾向が見られ る. これは溶鉄の硫黄の濃度が増加することによつて表 面酸化物の硫黄の濃度が増加し, 有効に働く反応界面積 の減少に原因するものと思われる，乙かし，1.0〜 1.3\% $\mathrm{S}$ の場合の $k_{\mathrm{m}}$ の平均值は $1.27 \times 10^{-4} \mathrm{~mol} / \mathrm{cm}^{2} \cdot \mathrm{s}$. $\operatorname{atm}^{1 / 2}$ で純粋な鉄系のそれに対して約 $10 \%$ 前後の低下 にすぎないので，実験誤差の範囲を考えると硫黄の影響 は注ぼ無視でさるものと見なされる，本研究とは測定条 件が異なつているが，浮遊溶融法による L.A. GREENBERG ら 2) の研究でも酸化速度におよぼす硫黄の影響は ないと報告している.

このように，溶鉄中の酸素と硫黄は酸化速度にほとん ど影響をあたえず，酸化速度は $\sqrt{P_{\mathrm{O}_{2}}}$ に比例すること は，物質移動律速を支持していると考えられる。

\section{3 反応温度の影響}

反応速度におよぼす温度の影響を測定することは，反 応機構を推定する有力な力法として，これまでたびたび 行われてきた.したがつて本研究でも, 酸素がス導入前 の温度以外の他の 条件を一定に保ち，1540 〜 $1680^{\circ} \mathrm{C}$ の温度範囲で測定を行つた．得られた結果が Arrhenius 型の式にしたがらと仮定して整理した結果を Fig. 14 に示す。これより見掛忷の速度定数の温度式として次式 を得た。

$$
\log K_{\mathrm{m}}=-4970 / 4.575 T+2.54
$$

(18)式より得られる見掛けの活性エネルギ $\left(E_{k_{\mathrm{m}}}\right)$ の 值は約 $5 \mathrm{kcal} / \mathrm{mol}$ の小さい值であり物質移動律速を支 持するように見える.しかし，本研究で仮定した反応モ デルによれば(9)式より $k_{\mathrm{m}}=(1 / 2) k_{\mathrm{L}} \cdot K^{\prime}$ であり見掛

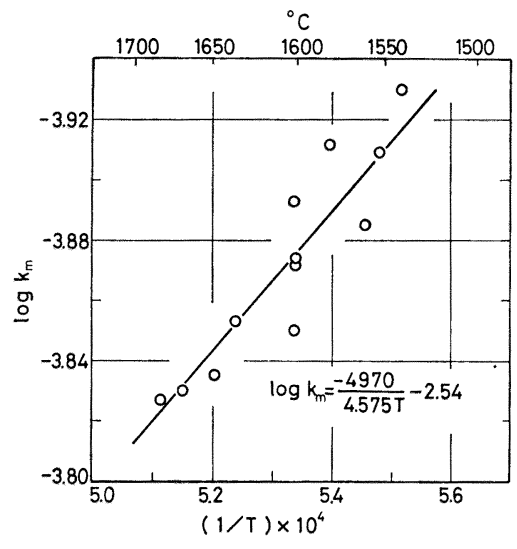

Fig. 14. Arrhenius plot for temperature dependence of the apparent rate constant.

けの活性化ェネルギは次式のように書ける。

$$
E_{k_{\mathrm{m}}}=E_{k_{\mathrm{L}}}+E_{k^{\prime}}
$$

ここで， $E_{k_{\mathrm{L}}}$ は物質移動の活性化エネルギ， $E_{k^{\prime}}$ は酸 素原子 1 モル $\left(1 / 2 \mathrm{O}_{2}\right.$ モル) が溶融酸化鉄中に溶解する 反応熱であり, 熱力学データより $E_{k^{\prime}}=-60 \mathrm{kcal} / \mathrm{mol}$ 程度の值が予想される。これより $E_{k_{\mathrm{L}}}$ の值としては 65 $\mathrm{kcal} / \mathrm{mol}$ 程度の值が見積もられ, 物質移動の活性化エネ ルギとしては大きすぎると言える.しかし，活性化ェネ ルギの物理的意味を知るためには反応機構についての十 分な解明が必要であり，溶融酸化鉄中の抎散種や抁散機 構, ガスー溶融酸化鉄界面のガス吸着の間題などについ て十分な研究がなされねばならない。しかし，これらの 問題はいまだ解決できない課題として残されており, 今 後の研究になたなければならない。

\section{5. 結論}

定容測圧法により，純酸素ガスによる溶鉄の酸化速度 を測定して，次の結果を得た。

1) 溶鉄の酸素ガスによる酸化過程は，反応初期にお ける酸素と溶鉄間の直接反応による発熱をともなら非常 に速い酸化過程と, 溶鉄表面に酸化膜を生成後, ガス/酸 化物/メタルの3相共存下で進行する比較的ゆつくりした 酸化過程よりなる。

2） 3 相共存下における $2 ， 3$ の酸化機構について考 察した. その結果, 反応速度は $V P_{\mathrm{O}_{2}}$ に比例し, ガス, 酸化物界面の酸化物側境界層に括ける物質移動律速を仮 定したモデル式によく一致する.

3 ) モリブデニウムや白金の板を使用し，高周波炉に よる溶鉄の攪拌の程度を変化させると, 反応速度も変化 し，攪拌の大きいほど反応速度は速くなる。 
4 ）酸化速度は溶鉄中酸素量に関係なく一定である. 硫黄の添加は反応速度をすこし遅くするが，その程度は 測定䛊差の中に入る程度である。

5 ) 以上の結果上り，ガス/溶融酸化鉄/溶鉄の 3 相共 存下における酸化速度は, ガス/酸化物界面の酸化物側境 界層における物質移動によつて律速されると考えられ る.

6) 見掛けの活性化エネルギとして $5 \mathrm{kcal} / \mathrm{mol}$ の低 い值が得られたが，その物理的意味については今後の検 討が必要である.

終わりに当たり, 本研究の遂行に協力した, 川崎製 鉄- 皆川俊則工学士, 帝国酸素・彦坂稔工学士, 東北大 学工学部・ 丸山信俊助手, 小倉勝広技官, および有益な 御討論をいただきました川崎製鉄技研・江見俊彦博士， 東北大学工学部金属工学科 ·菊池淳助教授, 不破祐名誉 教授の皆様に感謝いたします。

\section{交献}

1) $P$. A. Distin and S. G. White: Can. Met. Quart., 9 (1970), p. 419
2) L. A. Greenberg and A. McLean: Trans. ISIJ, 14 (1974), p. 395

3) S. K. VIG and W.-K. Lu: JISI, 209 (1971), p. 630

4 ) T. Снон, M. Kurata, and $M$. Inouye: Proc. Int. Conf. Science and Tech. of Iron and Steelmaking, Tokyo, (1971), p. 548

5 ) T. Emi, $W . M$. Boostein, and $R . D$. PehlKe: Met. Trans., 9 (1974), p. 1959

6) T. Emi and R. D. Pehlke: 同上 6B (1975), p. 95

7) P. Kofstad: High-Temperature Oxidation of Metals, (1966), p. 244 [N. Y., wiley]

8 ) P. Kofstad: 同上 p. 112

9 ) W. D. Kingery: J. Phys. Chem., 62 (1958), p. 898

10) W. M. Boostein and R. D. Pehlke: Trans. Met. Soc. AIME, 245 (1969), p. 844

11) R. D. Pehlke and J. F. Elliott: Trans. Met. Soc. AIME, 227 (1963), p. 814

12）長 隆郎，井上道雄：鉄と鋼，54 (1968), p. 19

13）萬谷志郎, 篠原忠広, 戸崎秀男, 不破 祐: 鉄と 鋼, 60 (1974), p. 1443 